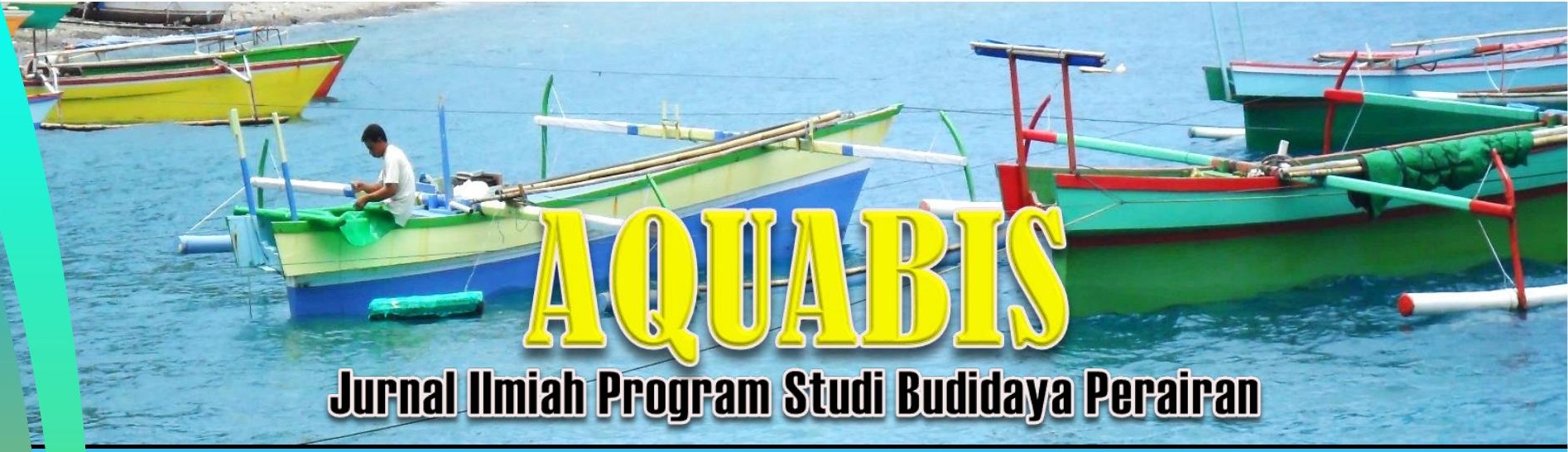

Volume 6 Nomor 1 Juni 2017

ISSN: 2301-5705

FAKTOR TEKNIS PENANGKAPAN TERHADAP DAMPAK TEKANAN POPULASI IKAN CAKALANG (Katsuwonus pelamis) DI PERAIRAN LAUT FLORES

Asruddin 1

KONSENTRASI LOGAM BERAT TIMBAL (PB) PADA SEDIMEN DAN IKAN NILA (Oreochromis niloticus) DI SUNGAI BIYONGA KABUPATEN GORONTALO

Sri Yuningsih Noor. 7

ANALISIS KELAYAKAN PANGKALAN PENDARATAN IKAN (PPI) TENDA KOTA GORONTALO DITINJAU DARI FASILITAS POKOK, FUNGSIONAL, DAN PENUNJANG

Muh. Yasin Umsini Putra Oli’ii dan Noval Saputra Yintili.... 13

BUDIDAYA IKAN AIR TAWAR SISTEM POLIKULTUR MENGGUNAKAN JARING TANCAP DI DANAU LIMBOTO

Yulianty Adipu

PEMANFAATAN KEONG MAS (Pomacea caniculata) SEBAGAI SUMBER BAHAN BAKU PAKAN IKAN

Titin Liana Febriyanti.

FREKUENSI PENCUCIAN YANG BERBEDA TERHADAP KEKUATAN GEL DAN PROTEIN LARUT GARAM SURIMI IKAN MANGGABAI (Glossogobius giuris)

Rahyuni Sy. Domili.

TELAAH KOMPOSISI IKAN KARANG DAN KOMUNITAS KARANG KELURAHAN BUNTA II DAN DESA MINAHAKI KABUPATEN BANGGAI Mohamad Sayuti Djau 


\title{
FREKUENSI PENCUCIAN YANG BERBEDA TERHADAP KEKUATAN GEL DAN PROTEIN LARUT GARAM SURIMI IKAN MANGGABAI (Glossogobius giuris)
}

\author{
Rahyuni Sy. Domili \\ Program Studi Budidaya Perairan Fakultas Ilmu- Ilmu Pertanian \\ Universitas Muhammadiyah Gorontalo \\ Email :youneerahyuni@gmail.com
}

\begin{abstract}
The research was aimed to know the effect of different washing frequency on Surimi of Manggabai fish (Glossogobius giuris) wich is gel strength and salt soluble protein. This experiment used experimental method with different washing factor treatment that is 1,2,3, and 4 times leaching and research parameter is gel strength and soluble salt protein of Surimi Manggabai fish (Glossogobius giuris). The research data was processed using a complete randomized design (RAL) analysis. Based on the value of gel strength and salt soluble protein, twice washing as the best treatment for gel strength value is 694.81 gram / cm and salt soluble protein is $13.38 \%$.
\end{abstract}

Keywords: Surimi, frequency of washing, gel strength, salt soluble protein

\begin{abstract}
Abstak
Penelitian ini bertujuan untuk mengetahui pengaruh frekuensi pencucian yang berbeda pada surimi ikan Manggabai (Glossogobius giuris) terhadap kekuatan gel dan protein larut garam. kekuatan. Penelitian ini menggunakan metode eksperimen dengan perlakuan faktor frekuensi pencucian yang berbeda yaitu 1,2,3, dan 4 kali pencucian dengan parameter uji yaitu kekuatan gel dan protein larut garam surimi ikan Manggabai (Glossogobius giuris). Data penelitian diolah menggunakan analisis ragam rancangan acak lengkap (RAL). Berdasarkan nilai kekuatan gel dan protein larut garam, diperoleh pencucian dua kali sebagai perlakuan terbaik untuk dengan nilai kekuatan gel sebesar $694.81 \mathrm{gram} / \mathrm{cm}$ dan protein larut garam sebesar 13,38\%.
\end{abstract}

Kata kunci : Surimi, frekuensi pencucian, kekuatan gel, protein larut garam

\section{PENDAHULUAN}

Gorontalo merupakan daerah dengan potensi perikanan air tawar yang cukup berlimpah. Salah satu ikan yang ada di danau limboto yaitu Ikan manggabai (Glossogobius giuris) (Suryandari dan Krismono, 2013). Ikan merupakan merupakan bahan pangan yang kaya protein dan dapat dimanfaatkan menjadi berbagai olahan hasil perikanan.

Saat ini bahan baku bakso, nugget, empek-empek dan makanan olahan lainnya berbahan baku daging sapi dan daging ayam yang memiliki kandungan protein tinggi akan tetapi kandungan lemaknya pun cukup tinggi. Kandungan lemak yang tinggi kurang baik bagi kesehatan apabila dikonsumsi dalam jumlah yang besar, oleh karena itu dibutuhkan alternatif protein yang cukup tinggi dan kandungan lemak yang rendah seperti ikan manggabai.

Surimi adalah salah satu olahan daging lumat dari daging ikan yang bisa digunakan sebagai bahan setengah jadi yang dijadikan bermacam- macam produk pangan lanjutan seperti bakso, otak- otak, nugget, pempek dan lain- lain. Salah satu syarat dari ikan yang bisa digunakan untuk bahan baku surimi yaitu yang memiliki kandungan protein tinggi terutama protein larut garam. Hasil penelitian pendahuluan terhadap komposisi kimianya, ikan manggabai ini memiliki protein yang tinggi yaitu $14,51 \%$, protein larut garam sebesar $6,82 \%$ dan lemak yang rendah $1,57 \%$ dari hasil tersebut dapat dikatakan ikan manggabai sangat cocok untuk bahan baku surimi.

Pembentukan gel elastis surimi dapat terganggu oleh protein yang larut air (sarkoplasma). Pencucian dapat meningkatkan kemampuan daging membentuk gel karena meningkatnya aktivitas myofibril (protein larut garam) sebagai pembentukan gel. Protein miofibril (kontraktil) yang terdiri dari aktin, miosin dan protein regulasi (tropomiosin, troponin dan aktinin). Gabungan aktin dan miosin membentuk aktomiosin yang sangat berperan dalam pembentukan gel. Pengukuran 
kadar PLG penting dilakukan untuk mengetahui kandungan protein miofibril dalam surimi yang berperan dalam pembentukan gel. PLG sangat berperan dalam proses pembentukan gel diakibatkan terjadinya agregasi antara aktin dan miosin pada saat diekstrak (Suzuki 1981). Faktor pencucian yang berpengaruh dalam pembentukan gel, diantaranya perbandingan antara daging dengan jumlah air, frekuensi pencucian dan suhu air (Lainer, 1992). Pada penelitian ini ikan beloso/manggabai yang dijadikan bahan baku dalam pembuatan surimi dengan frekuensi pencucian yang berbeda kemudian akan di lihat pengaruh frekuensi pencucian yang berbeda tersebut terhadap kekuatan gel dan protein larut garam dari masing-masing perlakuan.

\section{METODE PENELITIAN}

\section{Alat dan Bahan Penelitian}

\section{Alat Penelitian}

Peralatan yang digunakan untuk pembuatan surimi dan kamaboko meliputi: mixer, pisau, wadah, sendok, dan thermometer, kain kasa saring. Peralatan yang digunakan untuk analisis karakteristik surimi meliputi tabung reaksi, $\mathrm{pH}$ meter digital, kertas saring Whatmann nomor 1 , cawan porselin, labu takar $100 \mathrm{ml}$, desikator, glass wool, erlenmeyer, buret, gelas ukur, tabung Kjeldahl, labu lemak, soxhlet, desikator, oven, Rheoner jenis RE-3305 Scarsdale NY/Stable Microsystem, AAS (Atomic Absorption Spectrophotometer) merk Perkin Elmer.

\section{Bahan Penelitian}

Bahan-bahan yang digunakan untuk pembuatan surimi adalah ikan manggabai, garam, air, dan $\mathrm{NaCl}$. Adapun bahan-bahan yang diperlukan untuk analisis kekuatan gel dan protein larut garam surimi meliputi untuk analisis kimia seperti $\mathrm{K}_{2} \mathrm{SO}_{4}, \mathrm{HgO}, \mathrm{H}_{2} \mathrm{SO}_{4}$, tablet Kjeldahl, akuades, $\mathrm{NaOH} 40 \%, \mathrm{H}_{3} \mathrm{BO}_{3}$, $\mathrm{HCl}$, heksana, $\mathrm{NaCl}$, buffer, TCA, $\mathrm{K}_{2} \mathrm{CO}_{3}$ dan indikator.

\section{Rancangan Penelitian}

Penelitian ini menggunakan metode eksperimen dan deskriptif. Dengan rancangan percobaan yang digunakan adalah Rancangan Acak Lengkap (RAL). Penelitian dilaksanakan dalam dua tahap proses yaitu penelitian pendahuluan dan penelitian utama. Penelitian pendahuluan yang dilakukan untuk mengetahui apakah bahan baku ini bisa menjadi surimi yaitu dengan pengujian protein larut garam serta uji proksimat pada ikan manggabai segar. Sedangkan penelitian utama dilakukan pembuatan surimi dengan perlakuan pencucian sebanyak 1, 2, 3, dan 4 kali untuk melihat pengaruh frekuensi pencucian yang berbeda terhadap kekuatan gel dan protein larut garam surimi ikan Manggabai.

\section{HASIL DAN PEMBAHASAN Penelitian Pendahuluan}

1. Analisis Proksimat Ikan Manggabai

Hasil analisis proksimat ikan manggabai terdiri dari protein $14,51 \%$, lemak $1,57 \%$, kadar air 79,59\%, kadar abu 1,02\% dan protein larut garam $6,82 \%$. Hal ini menunjukan ikan manggabai termasuk jenis ikan berprotein tinggi, protein larut garam yang tinggi serta lemak rendah. Menurut Suzuki (1981) ikan yang tergolong berlemak rendah dan berprotein tinggi memiliki kandungan protein 15-20\% dan kandungan lemak lebih kecil dari $5 \%$. Jenis ikan ini sangat cocok untuk diolah menjadi surimi karena tingginya kadar protein dan rendahnya kadar lemak yang diharapkan mampu menghasilkan kekutan gel terbaik.

\section{Rendemen}

Analisis rendemen yang dilakukan dalam penelitian ini terdiri dari analisis rendemen daging dan analisis rendemen surimi. Hasil analisis rendemen terlihat pada Tabel 1 . Nilai rendemen yang semakin menurun disebabkan proses pencucian melarutkan bahan-bahan yang larut air seperti protein sarkoplasma, enzim-enzim pencernaan (terutama protease), garam-garam inorganik dan substansi berbobot molekul rendah (trimetilamin oksida).

Tabel 1. Analisis rendman daging dan analisis rendaman surami

\begin{tabular}{ccccc}
\hline $\begin{array}{c}\text { Berat } \\
\text { Daging } \\
\begin{array}{c}\text { Utuh } \\
\text { (A) }\end{array}\end{array}$ & $\begin{array}{c}\text { Berat } \\
\text { Daging } \\
\text { Lumat } \\
(\mathrm{B})\end{array}$ & $\begin{array}{c}\text { Berat } \\
\text { Surimi } \\
\text { (C) }\end{array}$ & $\begin{array}{c}\text { Rendemen } \\
\text { Daging } \\
\text { Lumat }\end{array}$ & $\begin{array}{c}\text { Rendemen } \\
\text { Surimi }\end{array}$ \\
\hline $1600 \mathrm{~g}$ & $624 \mathrm{~g}$ & $440 \mathrm{~g}$ & $39.00 \%$ & $27.50 \%$ \\
\hline
\end{tabular}

\section{Penelitian Utama \\ Penelitian Utama Tahap I Perlakuan Frekuensi Pencucian}

1) Kekuatan Gel

Nilai kekuatan gel kamaboko mengalami penurunan seiring dengan penambahan frekuensi pencucian. Pencucian daging ikan dengan frekuensi pencucian dua kali 
memberikan nilai kekuatan gel terbesar, yaitu $694.81 \mathrm{gram} / \mathrm{cm}$. Pencucian satu kali memiliki protein yang cenderung rendah yaitu 476,2 gram $/ \mathrm{cm}$ karena masih terdapat protein sarkoplasma sehingga kekuatan gel yang dihasilkan belum maksimal. sedangkan pencucian ke dua kekuatan gel meningkat karena hampir keseluruhan protein sarkoplasma telah larut dalam air pencucian. Laporan penelitian Fitrial (2000), kadar protein miofibril maksimal dicapai pada pencucian 2 kali pada mutu gel ikan cucut layam (Carcharinus limbus). Pencucian ke tiga dan ke empat nilai kekuatan gel-nya menurun, yaitu masing- masing 608,93 gram $/ \mathrm{cm}$ dan $473,37 \mathrm{gram} / \mathrm{cm}$. Penurunan nilai kekuatan gel ini disebabkan adanya penurunan aktivitas myofibril yang berperan dalam pembentukan gel, dimana kekuatan gel tersebut akan menurun seiring banyakya frekuensi pencucian yang dilakukan. Menurut Huda (2002), terjadinya penurunan kekuatan gel ikan diduga akibat bertambahnya kadar air, dan terjadi penurunan mutu akibat degradasi protein miofibril (Gambar 1).

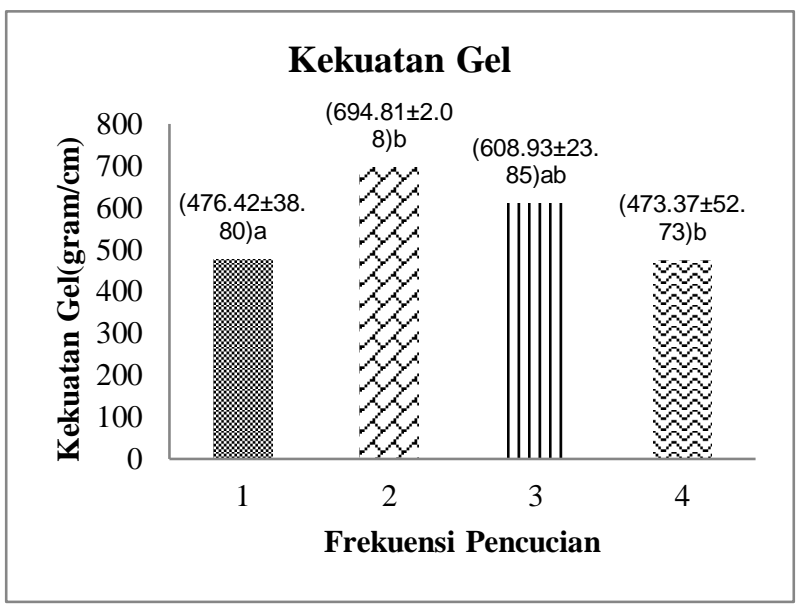

Gambar 1. Kekuatan gel dari frekuensi pencucian berbed

\section{2) Protein Larut Garam}

Protein larut garam surimi manggabai rata- rata $12,862 \%$ - 13,383\%. Dari Gambar 2 dapat dilihat protein larut garam mengalami peningkatan pada pencucian sebanyak 2 kali. Hasil penelitian Prawira (2008), protein larut garam naik pada pencucian pertama dan cenderung menurun dengan semakin banyaknya pencucian. Peningkatan nilai PLG surimi ikan manggabai disebabkan oleh larutnya protein sarkoplasma dan terbuang pada air pencucian. Hal ini diikuti dengan meningkatnya jumlah kelarutan protein miofibril pada pencucian dua kali yaitu 13.383 $\%$. Sehingga pencucian kedua dengan larutan garam $0,3 \%$, menghasilkan kekuatan gel yang lebih tinggi. Menurut Chaijan et al. (2004) dengan pencucian yang tepat, protein sarkoplasma bisa dibuang, sehingga protein miofibrillar lebih terkonsentrasi dan dapat berperan penting dalam pembentukan gel.

Penurunan presentase nilai PLG pada pencucian ke tiga $(13,056 \%)$ dan empat $(12,862 \%)$ diduga karena ada sebagian protein miofibril yang ikut larut dalam air pencuci akibat pencucian yang berulang-ulang, maupun menempel pada kain saring pada saat pemerasan. Lanier (1992) menyatakan, bagian kepala globular dari miofibril memiliki $80 \%$ komponen hidrofilik sehingga akan larut air saat proses pencucian surimi.

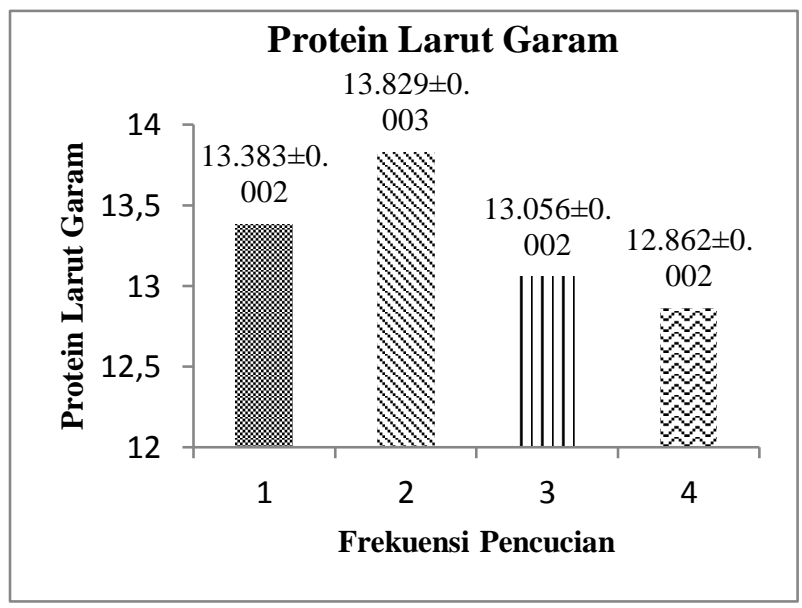

Gambar 2. Protein larut garam dari frekuensi pencucian berbeda

\section{KESIMPULAN}

Perlakuan frekuensi pencucian daging lumat secara umum berpengaruh nyata terhadap karakteristik surimi ikan manggabai yang dihasilkan. Frekuensi pencucian daging lumat 2 kali merupakan perlakuan terbaik dalam pembuatan surimi ikan manggabai dengan nilai kekuatan gel sebesar 694.81 gram $/ \mathrm{cm}$ dan protein larut garam sebesar $13.829 \%$. Berdasarkan hasil penelitian yang diperoleh maka diperlukan penelitian lanjut mengenai pembuatan aneka olahan dari surimi hasil pencucian terbaik yaitu 2 kali pencucian. Serta perlu diadakan uji lanjut terhadap karakteristik produk yang akan dibuat. 


\section{DAFTAR PUSTAKA}

Chaijan M, Benjakul S, Visessanguan W, Faustman C. 2004. Characteristics and gel properties of muscles from sardine (Sardinella gibbosa) and mackerel (Rastrelliger kanagurta) caught in Thailand. Food Research International 37:1021-1030.

Huda N, Aminah A, Babji AS. 2000. Effects of cryoprotectants on functional properties of dried lizardfi sh (Saurida tumbil) surimi. Malaysian Applied Biology 29(1): 9-16.

Lanier TC. 1992. Measurement of Surimi Composition and Functional Properties. Di dalam: Lanier TC, Lee CM, editor. Surimi Technology. New York (USA): Marcel Dekker, Inc
Prawira, A. 2008. Pengaruh Penambahan Tepung Alginat (Na- Alginat) terhadap mutu kamaboko berbahan Dasar Surimi Ikan Gabus (Channa striata). Program Studi Teknologi Hasil Perikanan. Institut Pertanian Bogor.

Suarti, et. Al 2016. Pembuatan Bakso Dari Biji Lamtoro (Leucaena leucocephala) Dengan Penambahan Putih Telur Dan Lama Perebusan. Agrium ISSN 08521077 (Print) ISSN 2442-7306 (Online) April 2016 Volume 20 No. 1

Suryandari dan Krismono, 2011. Beberapa Aspek Biologi Ikan Manggabai (Glossogobius giuris) Di Danau Limboto, Gorontalo. Bawal Vol. 3 (5): 329:336.

Suzuki T. 1981. Fish and Krill Protein: Processing Technology. London: Applied Science Ltd 